\title{
Realization of the Creative Potential of Future Engineers-Teachers of the Food Branch as a Factor of Self-Creation in the Professional Activity
}

\author{
O. Kurilo ${ }^{1, *}$ \\ ${ }^{1}$ Department of Vocational Education, Labor Training and Technology, Berdiansk State Pedagogical University, \\ Berdiansk, Ukraine \\ *Corresponding author. Email: olgakurilo_1990@ukr.net
}

\begin{abstract}
The paper scientifically substantiates realization of the creative potential of future engineers-teachers of the food branch as a factor of self-creation in professional activity. In particular, there is considered the essence of the professional activity of engineers-teachers of the food branch in the context of the creativity phenomenon as an ability to realize professional functions and to solve specialized problems and practical tasks of the professional (professional-technical) education and food branch of production. Possibilities of realization of the creative potential of future engineers-teachers of the food branch, based on rethinking and transformation of own experience at mastering the chosen specialty, are revealed. Creativity is considered as a condition of effective personal self-creation that determines the personal creative essence and provides a possibility of continuous changes in its structure. Contradictions, based on results of the analysis of the modern educational practice in training future engineers-teachers in the food branch and its development tendencies are established. Ways of the professional training improvement of future engineers-teachers in the food branch, oriented at realization of their creative potential, are determined. The effective mechanism of self-creation of future engineers-teachers in the food branch in the professional activity is determined as an orientation of their professional training at the optimal realization of the creative potential and provision of correspondent organizational-pedagogical conditions (activation of incentive motives to creative self-expression in the future professional activity; using of didactic possibilities of disciplines of the cycle of the professional and practical training in achieving expected results of creative type; organization of the psychological-pedagogical support as to formation of components of the readiness to the professional activity).
\end{abstract}

Keywords: Engineer-teacher, creative potential, food branch, professional activity, professional-technical

education, self-creation

\section{INTRODUCTION}

Under modern conditions the problem of formation of a human as a competitive creative person is the most urgent. An accelerated speed of scientific-technical development, transfer to market relations and fast changes in all spheres of human activity, especially in the food branch, need formation and development of creative specialists (in the context of our research - engineers-teachers), able to react fast and to work constructively, to make non-standard and creative solutions. Priorities of socio-economic development raise requirements to education that is a main factor in reproduction of the intellectual, spiritual and economic potential of society. Especially, the Law of Ukraine "On education" accents that the aim of education is the comprehensive development of a human as a person and the highest value of society, development of his/her talents, intellectual and physical abilities, education of high moral qualities, formation of citizens, able to conscious social choice [1]. That is why education must be directed on the development of creative potentials of a person, giving possibilities to manifest own creative abilities and satisfying needs in self-creation, selfrealization and self-confirmation. This important task may be successfully realized under condition of training highcompetent, professionally skilled specialists, especially, engineers-teachers of a certain profile, able to realize own creative abilities both at studying at higher school and in further professional activity that is of wide profile (because graduates of this specialty may occupy posts both in the sphere of production and in one of education) that needs constant correction of approaches to its realization under changing conditions of labor market, by higher educational institutions.

We connect the process of self-creation of future engineers-teachers in the food branch and their possibility to develop own creative abilities in the process of own 
creative professional activity with the notion of creative potential.

The notion "creative potential" is considered in works of both foreign and native researchers. At that this question is elucidated from different positions, namely: as a structural formation that includes talents, inclinations, interests, manifestations of general intellect, intuition, abilities and so on (V. Moljako [2], D. Boghojavlenska [3], E. de Bono [4], S. Rubinstein [5], O. Leontiev [6], O. Popel [7]); as four groups of personal qualities of creativity, namely: worldview, value, intellectual and willing qualities (G. Guilford [9], K. Taylor [10]); as a manifestation of the personal essence (P. Kravchuk) [11]; as a means of realization of creative and intellectual activity of a person (D. Boghojavlenska) [3]; as a process of revelation of own individuality by a human (E. Yakovleva) [12]; as a synthetic (integrating) quality that characterizes personal possibilities (N. Postaljuk) [13]; as a potential creativity (G. Glotova) [14]; as a cognitive creativity (K. Guskova) [15]; as a typical characteristic, which manifestation depends on creative uniqueness of a person (E. Varlamova, S. Stepanov [16]). Despite the wide studying of this question, there is no single definition of the notion "creative potential" and the problem of its realization in future engineers-teachers in the food branch as a factor of self-creation in the professional activity has not been studied yet.

\section{PURPOSE AND QUESTIONS OF RESEARCH}

The research aims to substantiate theoretically realization of the creative potential of future engineers-teachers of the food branch as a factor of self-creation in the professional activity.

Research tasks:

1. To consider the essence of the professional activity realization of future engineers-teachers of the food branch in the context of the creativity phenomenon.

2. To reveal possibilities of realization of the creative potential of future engineers-teachers of the food branch as a factor of self-creation in the professional activity.

3 . To determine ways of improvement of the professional training of future engineers-teachers of the food branch, oriented at realization of their creative potential.

\section{RESEARCH METHODS}

1. Analysis of normative-legal documents, scientific studies, philosophical and psychological-pedagogical literature for revealing special features of the creative professional activity of future engineers-teachers of the food branch and requirements to its realization.

2. Content-analysis and abstraction for specifying and concretizing the categorical apparatus as to understanding constructions of the creative professional activity, creative potential, self-creation process.
3. Synthesis, comparison, generalization of scientists' views on the problem of realization of the creative potential of future engineers-teachers of the food branch as a factor of self-creation in the professional activity, revelation of certain regularities and discrepancies, formulation of conclusions and determination of directions of further definition of the studied phenomena.

\section{CONTENT OF THE RESEARCH}

\subsection{The consider the essence of the professional activity realization of future engineers-teachers of the food branch}

Under today's conditions, requirements for a competitive specialist as a worker become higher, and professional tasks - more complicated. A human takes these challenges, consciously sets aims, strives for adequate solution of problems, works on him/herself (for own development and growth), achieve goals, chooses more complicated tasks, develops own abilities, professional competences, tries to correspond to higher standards, searches for possible ways of activity optimization and so on. A subject acts and it allows him/her to manifest and develop in own behavior (including professional one) such qualities, knowledge, skills, competences that correspond to growing requirements. So, self-development, revelation of own potential, creation of "Me"-conception are indicators of self-creation as a base of professional formation of a person [17].

A modern engineer-teacher is a specialist with a double integrated competence. The list of possible posts of engineer-teacher is presented in the National classifier of Ukraine SC 003:2010 «Classifier of professions» [18] and in the Directory of qualifying characteristics of workers' professions [19]. According to these documents, a future engineer-teacher can occupy posts of junior specialists and professionals in the education branch, posts of specialists, professionals, managers and officials - in the production one $[18 ; 19]$, that is can realize professional functions in both pedagogical and engineer activity.

Just the multifunctional and wide profile type of engineerpedagogical activity makes it creative at solving professional-pedagogical and engineer-technical tasks. As it is noted by L. Gurier and L. Redin, the ability to creative activity, creativity and independence in making decisions, mastering scientific-practical skills are main features, organically inherent to the engineer-pedagogical profession, and most important preconditions of high competitiveness of one's potential at employment [20]

Creativity in the professional activity of engineers-teachers has own features. In the production sphere the special type of creativity is engineer one, more often connected with non-algorithmized activity, namely: improvement of old technique and technologies or creation of new technical or technological means with a production and social importance; introduction of new, more progressive forms 
of labor and production organization. The need in engineer creativity arises, when in the production process traditionally known solutions, methods and means don't satisfy needs, and it is necessary to offer or to invent new solutions [21].

In the context of our research, the interest is the creative activity of engineers-teachers of the food branch. The professional activity of engineers-technologists is directed on the search for new ideas, creative transformation, solution of non-standard tasks in production.

The professional activity of engineers-technologists needs continuous creative searching, setting creative goals, forming plans and projects of innovative development of an enterprise, systematic work for a certain scientific, technical idea or project, creative use of standardized elements, norms of scientific and technical activity, bringing ideas to introduction into the production process. That is the engineer activity is oriented on solving technical-technological problems and tasks of a certain production branch, especially food one.

In the pedagogical sense "creativity" is characterized by personal and social importance of obtained results in overcoming certain contradictions, appearing in the educational process. We enjoy the experience of $\mathrm{V}$. Andreev, who interprets creativity as "as one of the types of human activity, directed on solving contradictions (creative task solution), for which objective (social, material) and subjective conditions (knowledge, skills, creative abilities) are necessary, which result is new and original, personally and socially important and also progressive" [22]. The researcher considers the problem of pedagogical creativity as "a science about the pedagogical system of two dialectically conditioned types of human activity: pedagogical education and self-education of a person in different types of creative activity and communication for comprehensive and harmonic development of creative abilities of both separate person and certain group" [22].

So, creativity plays the important role in the professional activity of engineers-teachers, favors effective solutions of specialized problems and practical tasks of the professional (professional-technical) education and the food branch.

At that creativity acts as a factor and necessary condition of the effective self-creation of a person that determines its creative essence. The role of creativity in self-creation intensifies the creativity process of a person him/herself [23]. An essential sign of the process of self-creation is its active character, organic penetration in different manifestations of activity and personal behavior. This process is an internal, active principle, pivotal essential ability that provides a possibility of continuous changes in the personal structure as a dynamic, self-regulating and open system [23].

We agree with the idea of N. Negovska, who accents the fact that a successful realization of the professional activity of an engineer-teacher directly depends on the content and organization of his/her professional training at a higher educational institution [24].
We understand professional training of future engineersteachers as a system of external and internal factors: firstly, the organized process of formation of the readiness to realizing professional tasks, main professional functions that correspond to certain types of the engineerpedagogical activity; secondly, the process of mastering general and special competences, based on realization of potential possibilities of higher education applicants.

The ability to self-determination, self-development, selfimprovement is realized, when a person becomes a real subject. Moving forces of personal self-development are localized in a person him/herself, and external factors lose their programming role [25]. The most constructive way of self-creation is reflexive rethinking and transformation of own experience, opening of the potential and development of a person by own efforts, by activity [17].

\subsection{The possibilities of realization of the creative potential of future engineers-teachers of the food branch}

The term potential is translated from Latin as "force" and is interpreted in the wide sense as sources, means, reserves that are present or can be mobilized for attaining a certain aim [26].

Creative potential is a system-creating quality of a person that reflects a type of interconnection of all human abilities and integrative phenomenon that combines essential creative forces of a person in real practice and overactivity relations [11].

We share an idea of the researcher P. Kravchuk that a "key moment in the training system of a specialist with a higher education is the development of his/her creative potential, because just the development of searching, analytic, transforming abilities of a student rises a mastering level of professional knowledge and also abilities and skills of social orientation on new conditions, fast reaction to changes of a situation, making operative decisions" [11]. So creative person is a person, able to realize own creative potential through creative activity. At that the potential itself acts as one of most important qualities of a creative person, as a source of creative activity under condition of which formation and development, a person transforms into creative one [27].

The creative professional activity of a future engineerteacher may be realized at different levels and by different means, but in any case it is constructed on principles of his/her competences and readiness to creative professional activity under conditions of organization of both educational process and production sphere of any profile. The professional training of future engineers-teachers of any profile is connected with formation of the integral professional competence or its components - general or special, especially it concerns information, communicative, organizational, managerial and creative ones. Attention is paid to certain aspects of the readiness to the professional activity in the context of creation of professional-pedagogical projects, using information- 
communicative technologies, introduction of personally oriented learning and so on. It is accented on the necessity of development of the creative potential and creativity of future specialists, especially, in the food branch.

\subsection{The ways of improvement of the professional training of future engineers- teachers of the food branch}

Depending on a scientific-pedagogical aim and expected results of the professional training of engineers-teachers of a certain profile, researchers offered ways of its improvement, such as: coordination of pedagogical component with other training ones and succession in mastering just pedagogical experience achievements; integration of engineer and pedagogical components, based on the principle of unity and interconnection of content and procedural aspects of the educational process; use of the integrative approach to studying general educational and professionally oriented disciplines, based on information technologies; use of the creative approach at solving theoretical and practical tasks; formation of separated knowledge, abilities and skills and professionally important abilities, qualities and skills (for example, projecting knowledge and skills, researching skills, ability to learn something new continuously, to find and to use necessary information; humanistic worldview, conscious life-creation, activity, independence, responsibility, creativity, pushfulness; ability to see and to solve problems, ability to self-cognition, selfdetermination, self-development and so on); organization of subject-subject interaction between a teacher and a student that provides realization of their intellectual, communicative, regulatory-behavioral resources and personal potential as a whole; formation of an experience of the creative professional activity, based on quasiprofessional actions at solving professionally oriented tasks and so on.

But these ways of improvement of the professional training of future engineers-teachers only partially satisfy requirements, set to creative professional activity. Thus, according to the results of experimental works of a series of scientists, the creative (high) level of formation of general or special competences after the targeted influence is: $25.4 \%$ (J. Gvozdetska) [28], 34.06\% (O. KerekashaPopova) [29], 32.8\% (J. Kozak) [30], $18.78 \%$ (O. Krivilyova) [31], 28.1\% (M. Mefanyk) [32], 10.59\% (O. Potapchuk) [33], 16.08\% (A. Shaura) [34] and others. In the category of higher education applicants, whose professional training was realized, based on the traditionally formed practice, this percent is even lower: $8.8 \%$ (Y. Gvozdetska) [28], 22.73\% (O. KerekeshaPopova) [29], 26.4\% (Y. Kozak) [30], $9.98 \%$ (O. Kriviliova) [31], 15.6\% (M. Mefanyk) [32], 9.88\% (O. Potapchuk) [33], 7.58\% (A. Shaura) [34] and others.

Taking into account the results of the analysis of the modern educational practice in training future engineersteachers of the food branch and its development tendencies, there have been established contradictions, appeared between:

- grown requirements to the professional activity of future engineers-teachers of the food branch and their training condition;

- the necessity to raise the level of the creative professional activity readiness of future engineers-teachers of the food branch and the absence of an integral model of this process;

- the need of future engineers-teachers of the food branch in professional growth and insufficient orientation of the training on the development of the creative personality of a learning subject;

- potential possibilities of the professional training of future engineers-teachers of the food branch at pedagogical educational institutions and their insufficient realization in practice.

So, we connect prospects of further searches in our research with verification of the formulated hypothesis, based on the idea that intensification of the staff potential of the food branch as to the readiness to orient fast in changing labor conditions in the sphere of branch and education is provided, especially, by the training of future engineers-teachers of the food branch to the creative professional activity, namely: orientation of the training on the optimal realization of the creative potential of future specialists and creation of correspondent organizationalpedagogical conditions (activation of incentive motives to creative self-expression in the future professional activity; using of didactic possibilities of disciplines of the cycle of the professional and practical training in achieving expected results of creative type; organization of the psychological-pedagogical support as to formation of components of the readiness to the creative professional activity).

\section{CONCLUSION}

Summarizing the aforesaid ideas, we may formulate the following conclusions.

Engineers-teachers of the food branch are specialists with double integrated competence, manifested in the ability to realize professional functions in both pedagogical and engineer activities. Their creative professional activity favors effective solutions of specialized problems and practical tasks of the professional (professional-technical) education and food branch under changing labor conditions.

Creativity acts as a factor and necessary condition of effective self-creation of person that determines his/her creative essence and provides a possibility of continuous changes in its structure. Reflexive rethinking and transformation of own experience, opening of the potential and personal development by own efforts in the professional activity is the most constructive way of selfcreation. The potential acts as one of most important qualities of a creative person, as a source of creative activity under condition of which formation and development, a person transforms into creative one. 
The effective mechanism of self-creation of future engineers-teachers in the food branch in the professional activity must be an orientation of their professional training at the optimal realization of the creative potential and provision of correspondent organizational-pedagogical conditions.

\section{REFERENCES}

[1] About education: Law of Ukraine. Available at: https://zakon.rada.gov.ua/laws/show/2145-19 (In Ukrainian).

[2] Moljako, V.O. (2006). Abilities, creativity, talent: theory, methods, research results. Zhytomyr: Ruta. 320. (In Ukrainian).

[3] Boghojavlenskaja, D.B. (1983). Intellectual activity as a problem of creativity. Rostov n/D. 173. (In Russian).

[4] De Bono, Edward. (1993). Serious Creativity: Using the Power of Lateral Thinking to Create New Ideas.

HarperBusiness. 338.

[5] Rubinshteyn, S.L. Fundamentals of general psychology. Available at:

http://yanko.lib.ru/books/psycho/rubinshteyn=osnovu_o bzhey_psc.pdf. (In Russian).

[6] Leontev, A.N. (1977). Activity, consciousness, personality. M. 304. (In Russian).

[7] Popel, A.A. (2005). Psychological conditions for the development of social creativity of students in the process of professional training. Candidate's thesis. N. Novgorod. 217. (In Russian).

[8] Lvova, I.V. (2005). Psychological factors in the development of personality creativity. Candidate's thesis. Novosibirsk. 203. (In Russian).

[9] Guilford, J.P. (1975). Creativity: a quarter century of progress. Perspectives in Creativity / Eds.: L.A. Taylor, J.W. Getzels. Chicago: Aldme. pp.37-59.

[10] Taylor, C.W. (1988). Various approaches and definitions of creativity. The nature of creativity. Cambridge: Cambr. Press. pp.99-126.

[11] Kravchuk, P.F. (1992). Formation of creative potential of the person in the system of higher education. Extended abstract of Doctor's thesis. M. 32. (In Russian).
[12] Yakovleva, Ye.L. (1997). Psychology of development of creative potential of the person. M. 224. (In Russian).

[13] Postalyuk, N.Yu. (1989). Creative style of activity. Pedagogical aspect. Kazan. 204. (In Russian).

[14] Romenecj, V.A. (2001). Psychology of creativity. K.: Lybidj. 288. (In Ukrainian).

[15] Guskova, Ye.A. (2007). Psychological conditions for the realization of the creative potential of students in the educational process of the university. M. 212. (In Russian).

[16] Varlamova, Ye.P. \& Stepanov, C.Yu. (2002). Psychology of creative uniqueness. M. 256. (In Russian).

[17] Prorok, N.V. (2009). Self-improvement and selfcreation - the basis of professional development of the individual. Problems of modern psychology, issue 5.pp. 367-379. (In Ukrainian).

[18] National Classifier of Ukraine DK 003: 2010 "Classifier of professions". Available at: https://hrliga.com/docs/327_KP.htm. (In Ukrainian).

[19] Handbook of qualification characteristics of workers' professions. Available at: http://search.ligazakon.ua/1_doc2.nsf/link1/FIN11827.ht ml. (In Ukrainian).

[20] Gure, L.I. \& Redin, L.V. (2004). Development of creative qualities of students of a technical university in the process of methodological training. Integration of education. 3 (36). pp.126-129. (In Russian).

[21] Gaskova, Ye.Ye. \& Pirogova, Yu.Yu. Engineering creativity. Available at: http://conf.sfu-

kras.ru/sites/mn2011/thesis/s11/s11_10.pdf. (In Russian).

[22] Andreev, V.I. (1988). Dialectics of education and self-education of creative personality: basics of creativity pedagogy. Kazan. 238. (In Russian).

[23] Boryshevsjkyj, M.J. (2012). Self-creation of personality and socio-psychological essence are determinants of formation and development. S.D. Maksymenko (Eds.). Problems of general and pedagogical psychology. K. (Vols. XIV). (Part 1). pp.28-35. (In Ukrainian).

[24] Negovska, K.I. (2011). The specific aspect of the formulation of the specialty of an engineer-teacher in 
the context of faculty training. Pedagogical Sciences. 90. 130-133. (In Ukrainian).

[25] Serdjuk, L.Z., Jablonsjka, T.M., Danyljuk, I.V., Penjkova, O.I. \& Volodarsjka, N.D. (2015).

Psychological and pedagogical foundations of the process of self-creation of personality. L.Z. Serdjuk (Eds.). K.: Pedaghoghichna dumka. 197. (In Ukrainian).

[26] Nikolajenko, L.I. (2016). Creative potential of personality as a subject of foreign and domestic researches: theoretical analysis. Scientific review. 1 (22). 1-6. (In Ukrainian).

[27] Jemchyk, O.Gh. (2015). The problem of creative potential of the individual in the scientific and pedagogical heritage. Pedagogical sciences: theory, history, innovative technologies. 5 (49). 116-125. (In Ukrainian).

[28] Ghvozdecjka, Ju.V. (2018). Formation of professional competence of future teachers of basics of food production technologies in the process of professional training. Extended abstract of candidate's thesis. Umanj. 25. (In Ukrainian).

[29] Kerekesha-Popova, O.V. (2020). Formation of managerial competence of future engineers-teachers in the process of professional and pedagogical training. Extended abstract of candidate's thesis. Berdjansjk. 23. (In Ukrainian).
[30] Kozak, Ju.Ju. (2020). Formation of graphic competence of future engineers-teachers of computer profile in higher education institutions. Extended abstract of candidate's thesis. Khmeljnycjkyj. 23. (In Ukrainian).

[31] Krivilova, O.A. (2018). Design of psychological and pedagogical training for maybutic victories in professional and technical naval bases. Extended abstract of Doctor's thesis. Khmeljnycjkyj. 37. (In Ukrainian).

[32] Mefanik, M.S. (2020). Preparation of future engineers-teachers for the use of communication technologies in vocational training of students of vocational schools. Extended abstract of candidate's thesis. Dnipro. 23. (In Ukrainian).

[33] Potapchuk, O.I. (2016). Formation of readiness of future engineers-teachers for professional activity by means of information and communication technologies. Extended abstract of candidate's thesis. Rivne. 22. (In Ukrainian).

[34] Shaura, A.Ju. (2017). Methods of teaching food technology to future teachers of vocational education. Extended abstract of candidate's thesis. 26. (In Ukrainian). 